\title{
The paradoxes of necessity: fail forwards neoliberalism, social reproduction, recombinant populism and Poland's 500Plus policy
}

DOI:

10.1177/0309816819880798

\section{Document Version}

Accepted author manuscript

Link to publication record in Manchester Research Explorer

Citation for published version (APA):

Shields, S. (2019). The paradoxes of necessity: fail forwards neoliberalism, social reproduction, recombinant populism and Poland's 500Plus policy. Capital \& Class, 43(4). https://doi.org/10.1177/0309816819880798

\section{Published in:}

Capital \& Class

\section{Citing this paper}

Please note that where the full-text provided on Manchester Research Explorer is the Author Accepted Manuscript or Proof version this may differ from the final Published version. If citing, it is advised that you check and use the publisher's definitive version.

\section{General rights}

Copyright and moral rights for the publications made accessible in the Research Explorer are retained by the authors and/or other copyright owners and it is a condition of accessing publications that users recognise and abide by the legal requirements associated with these rights.

\section{Takedown policy}

If you believe that this document breaches copyright please refer to the University of Manchester's Takedown Procedures [http://man.ac.uk/04Y6Bo] or contact uml.scholarlycommunications@manchester.ac.uk providing relevant details, so we can investigate your claim.

\section{OPEN ACCESS}


The paradoxes of necessity: fail forwards neoliberalism, social reproduction, recombinant populism and Poland's 500Plus policy

Stuart Shields

University of Manchester, UK

The paper asks why Poland's populist Prawo i Sprawiedliwości [Law and Justice] government promotes progressive forms of social reproduction in the context of the supposed crisis of neoliberalism. It illustrates how populism is a response to the ongoing social ambiguity of postcommunist transition that redefines and recombines existing and novel political and social resources that are built, both on and with, existing social arrangements in Poland. It achieves this by analysing the current government's flagship child benefit programme: 500Plus. The paper claims that certain gender norms construct hegemonic neoliberal and populist discourses that legitimise particular policies, illustrating this by bringing into dialogue Janine Brodie's neoliberal 'paradox of necessity', with the notion of 'fail forwards' neoliberalization. The 500Plus policy remains ridden with contradiction, on the one hand a potentially progressive intervention in social reproduction, that deals with the crisis mode of society but that simultaneously helps ensure the continuation of neoliberalisation.

(150 words) 


\section{Introduction}

Contemporary politics is dominated by a hysteria fearful of the return of one of Europe's historical spectres: the far right in the guise of populist political parties across the continent. Wherever we look populist parties are gaining ground in elections, further increasing evidence of the mobilisation of the far right. It is as if Gramsci's "morbid symptoms" have emerged in the decade since the global financial crisis and the supposed interregnum between pre-crisis neoliberalism and whatever will eventually follow the supposed death of neoliberalism after the crisis. That a decade on from said crisis we are still discussing neoliberalism hints at the need for alternative ways of thinking about relations between neoliberalism and the conjunctural recombinant populism. This is not a sharpening of the contradictions, nor a paradox of neoliberalism to be explained away as another step towards the inevitable victory of progressive social forces but rather the latest settlement in favour of capital, as neoliberalism yet again, fails forwards.

In reflecting on one such contradiction the paper asks how and why regressive recombinant populist governments promote progressive forms of social reproduction in the context of the supposed crisis of neoliberalism. I utilise the idea of recombination to illustrate how agents understand the reemergence of populism as a response to the ongoing social ambiguity of transition, enabling them to redefine and recombine existing and novel political, social and cultural resources that are built, both on and with, the ruins of existing populist discourse in Eastern Central Europe. This adds nuance to the limitations of generic ahistorical concepts such as populism for explaining political processes.

The paper responds to this in relation to one such national case study of the process, Poland, to offer reflections on the role of gender norms in constructing hegemonic neoliberal and populist economic discourses that legitimise policy reforms in the EU. This illustrates wider concerns in the European political economy. The paper contributes to other analytical work on neoliberalism which has shown how capitalism in its contemporary neoliberal form continues notwithstanding trenchant criticism about the extent to which 'actually existing neoliberalism' may be found in different spaces and scales of governance rather than to expunge the term altogether due to its elasticity (Babidge and Belfrage, 2017). Furthermore, the paper engages with the contradictions in contemporary policy and rhetoric on gender equity analysis of neoliberalism.

The 500Plus policy is the current Polish government's flagship child benefit programme. Introduced in April 2016 500Plus guarantees families with two or more children 500 Polish złoty per month. I return to this in more detail in section four of the paper, but for now this focus is driven firstly because Poland is a significant departure point from which to elaborate critiques of neoliberalism given the country's early embrace and committed adherence to neoliberal forms. The rhetoric of the neoliberal 'miracle' of Poland celebrates the nation's economic growth in relation to its Eastern Central European neighbours. Second, especially if and when Brexit takes place, Poland will be one of the bigger players in EU politics. It is also supposedly the location of one of the most virulent examples of the populist turn associated with the political party Prawo $i$ Sprawiedliwości (PiS) [Law and Justice]. The government have been in power since 2015, combining a particularly arcane brand of Catholic authoritarian social conservatism, renewed welfare commitments, and seemingly permanent conflict with the EU, particularly over reforms to the judiciary. For critical scholarship this raises important praxeological questions about how we develop and promote progressive alternatives to neoliberal regimes.

To address this, the paper is divided into four main sections. First, the paper outlines the implications of the last decade of crisis in Eastern Central Europe. It does this to begin to contextualise the impact of this period on social reproduction in the region. Second, the paper 
engages with a particular formulation of social reproduction, Janine Brodie's neoliberal 'paradox of necessity', extending it to engage with the notion of fail forwards neoliberalization (Brodie, 2003). As Hilgers argues, 'the effects of neoliberal policies are anchored in bodies' (Babidge \& Belfrage, 2017). Third, the paper returns focus to Poland, exploring one particular response to the latest paradox of neoliberalism, the emergence of recombinant populist social forces. The fourth section then illustrates how the 500Plus policy response remains ridden with contradiction, on the one hand a progressive intervention in social reproduction, that deals with the crisis mode of society but that simultaneously help ensures the continuation of regressive neoliberalisation.

\section{The 'crisis' in Eastern Central Europe and social reproduction}

In this section of the paper I want to offer some context for the later discussions of populism in Poland. The broad starting point for the analysis is to outline the impact of the last decade of crisis in Eastern Central Europe and then begin to reflect on how theorising post-communist transition as social reproduction might be useful in explaining the current conjuncture. The restoration of Eastern Central Europe to the capitalist global political economy after 1989 occurred predominantly through neoliberal shock therapy (Hardy, 2014; Shields, 2012). Compared to Western European capitalist economies that have had an extended period of restructuring after the 1970s crisis, Eastern Central Europe compressed change into a muchcurtailed period. Despite the promises of neoliberal shock therapy the region has remained stuck in low level, low-tech production (Bohle and Greskovits, 2012) with acute socio-economic variegation despite the occasional 'cathedral in the desert' (Hardy, 1998).

It is probably little surprise then that the global financial crisis, plunged much of [Eastern Central Europe] into a deep recession, with the region, on average, suffering a more severe reversal of pre-crisis output trends than any other region of the world economy. While the worst case scenarios of systemic currency and banking crises did not occur, the magnitude of the recession was extremely severe (Connolly, 2012, 64).

The region is used to the deleterious social and economic effects of recurrent crisis. Recent history includes the various crises of a half century of communism, the economic crisis of transition, or the migration crisis, before we even think about the longue duree. The recent global financial crisis has imported a further round of shock therapy qua austerity into the region and with it the gendered and racialized dimensions. As Myant argues, the neoliberals have won and their response to the organic crisis "so far looks like being a move towards a smaller state and more unequal society" (Myant et al., 2013, 408). The Polish anomaly is that the 500Plus policy means increased state intervention and higher spending.

Pivotal to that smaller state and unequal economy is the reconfiguring of gender norms to fit the neoliberal project. Gramsci offers a useful starting point for discussion when he explores 'the sexual question' and the importance of the private sphere and sexual lives for Fordism. Fordism, for Gramsci, was reconfiguring a new man and woman for a new productive regime that was "in a backward state" when compared to other workers (Gramsci, 1971, 292). In a prescient echo of the contemporary period Gramsci discusses concerns in the capitalist core around the ratio of young to old, the segmentation of immigrant workers, and the contradictions of constructing the "new man" that is not, "imposed from the outside, if it is proposed by a new form of society, with appropriate and original methods" (Gramsci, 1971, 303). Gramsci spends a lot of time in that note considering how the social conditions for generating hegemony are maintained with the intervention of the state apparatus (Gramsci 1971: 181-2). Oddly enough, the resonance 
with contemporary Poland is startling, as the state "[inserts itself] into traditional puritanism and presenting themselves as a renaissance of the pioneer morality and as the 'true' America" (Gramsci 1971: 304). For America, read Poland, and the recalibrating of family values and conservative attitudes to sexuality in recent years.

As the rich literature on post-communist transition demonstrates, ideas of socially constructed and historically specific norms of masculinity and femininity remain at the forefront of neoliberal projects within the former Soviet Union and the debates on social, economic and political reform, alongside discourses of modernisation and nationalism have centred upon contestation over the meanings of gender roles and relations (Kuehnast \& Nechemias, 2004). Gender traverses formal and informal spheres and non-economic spaces (Gibson-Graham, 2006). Female gender roles traverse formal and informal economies and while some note the way this creates resilient subjectivities it is also a mechanism for neoliberalisation to ensure the broader project is stabilised through the remaking of gender and class relations. The restructuring of the relations of production under neoliberalism requires an examination of the changing relations of social reproduction taking gender seriously.

What might a conscious focus on social reproduction add to the Gramscian discussion above? Social reproduction is constituted by first, the biological reproduction of the species; second, the reproduction of the labour force and third, the reproduction and provision of caring needs (Bakker, 2007, 541). The study of social reproduction alerts us to analysis of global processes from the perspective of the everyday, rejecting the notion of neoliberalism as top-down imperative (Elias \& Rai 2019). Gender norms underpin the value assigned to different types of work involved in social reproduction, and the different roles and responsibilities assigned to men and women in a gendered division of labour. Women tend to occupy low-pay, low-status sectors of service and undertake a disproportionate share of unpaid work. The notion of a market populated by equal rational actors conceals and perpetuates inequalities (Rai, 2004: 582-584). Gender operates across the global political economy from the level of ideology and representation, in social relations and to the body (Marchand \& Runyan, 2000: 8).

To turn attention back to Eastern Central Europe, much of the existing literature on postcommunist transition frames it as a liberal path from a backwards 'east' to modernity in the shape of the west. Few, if any contingencies are broached as alternatives (Hörschelmann, 2002). This then tends to emphasise a neoliberal understanding of the formal economy, ignoring how gender crosses formal, informal and even non-economic spheres. Similar to how the political economy of social reproduction is often omitted in International Political Economy analyses (Bakker, 2007) the same occurs in analysis of post-communist transition with social reproduction all too often marginalised as potential contribution except for where it is evidently co-opted, as the regions development bank indicates "Gender equality is an important component of the development and transition processes in particular to better leverage the untapped potential of women in emerging markets." (EBRD, 2010: 4).

However, the co-option of the discourse of social reproduction in contexts like this, fails to identify how resolving untapped potential ignores the systemic nature of the crisis of women working. The increase in wage labour necessary to sustain the household is matched by the reversal in state provision. The crisis of care this induces means that policies like 500Plus are an anomaly when who bears the cost of social reproduction is all too often ignored. The lack of recognition of the costs of social reproduction are often only noticed when it is dangerously depleted and people are unable to adequately reproduce their livelihoods. For Rai, Hoskyns and Thomas, depletion through social reproduction is "the level at which the resource outflows exceed resource inflows in carrying out social reproductive work over a threshold of 
sustainability, making it harmful for those engaged in this unvalued work" (Rai et al 2013: 3-4). There are three key aspects of this: the move of women into paid work; the commercialisation of services; the changing functions of the state. If labour power cannot be reproduced this is a crisis for capital and as Dowling indicates, "consequently, we can ask whether there is a point at which a given social configuration is forced to change in response to the impossibility of extracting further surplus value from a particular social organisation of labour" (Dowling 2016: 454) as evident in the Polish context for the introduction of the 500Plus policy.

The paper turns to that issue more fully when considering the PiS 500Plus policy below as a form of response to depletion. It begins to query whether the apparently progressive content of PiS's policy is not so enlightened as it first appears, but a renewed form of neoliberal social innovation as neoliberal social forces attempt to appropriate social reproduction and increasingly responsibilise neoliberal subjects to rescue the wider problems faced in the current conjuncture and the implied challenges to European competitiveness. Thus gender differences are dialectically both intensified and eroded (Brodie, 2003). Before exploring the empirical details of the Polish case, the paper further explores the articulation between neoliberalism and social reproduction through Brodie's lens of the paradox of necessity.

\section{The parodox of necessity and fail forwards neoliberalism}

The previous section indicated why social reproduction might be a useful point to begin thinking about contemporary Poland. In this section the paper teases out the linkages between one particular aspect of social reproduction, Janine Brodie's paradox of necessity and brings that into dialogue with the contemporary debate on fail forwards neoliberalism and show how these two can shed light on both the recombinant populist turn and social reproduction.

One crucial aspect of the social reproduction literature that might help connect the disparate strands in our discussion of neoliberalism and populism is Janine Brodie's work. Neoliberalism has been characterised by the tendency to ignore its manifest failures without impeding policy makers from prescribing ever more enthusiastic iterations of the same (or at least similar) neoliberal policies that failed in the first instance (Peck et al 2012; Soederberg 2014). It is never the situation that we have too much neoliberalism, but rather too little. Brodie's work on Canada is applicable anywhere governments engaged in successive rounds of labour market deregulation. Efforts to facilitate 'flexible' labour markets have led to a growth in part-time and causal work to reduce wage costs but also to curb non-wage benefits entitlements. The combination of welfare reform and flexible labour market policies compounded women's already unequal position in labour markets more generally. The everyday activities of social reproduction have been replaced by market-based, privatised entitlements for those who can afford them (Elson 2002; Brodie, 2003). As Bakker notes, this paradox could be explored with respect to a range of state forms in the global North and South in future research on social reproduction, and the last two sections of the paper will reveal the particular form of this development in Eastern Central Europe and the contradictory responses in Poland. Given the discussion about social reproduction remember Poland occupies an unusual space in wider political economy as it is neither global North, nor global South, that does not fit the established welfare state model of the industrialised model of workplace, home and family (Van Hoven 2004).

Brodie's historical analysis of laissez faire's threat to human security is a powerful heuristic for thinking through the contemporary application of neoliberalism, and how it was "imposed on the Global South and the former Communist bloc" (Brodie, 2003, 48) via the processes we know now as the new constitutionalism (Gill, 1995). The new constitutionalism reveals how neoliberal policies have been institutionalised through their juridical insulation from democratic 
accountability. Such legal constraints bind states into particular policy process routes. This serves to "'lock in' commitments to disciplinary neo-liberalism and to 'lock out' other potential political economy alternatives", (Gill, 2008: 79). In the immediate post-communist period this meant the application of a particular set of policies: rapid privatisation, deregulation and liberalisation, often termed shock therapy. What constitutes neoliberalism at any specific point in time or space is open to revision. Alongside Brodie's intervention, this develops the notion that the state intervenes to underwrite capitalism and the "shifting interface between processes of production and social reproduction" to repair the worst effects on individuals but that this maintains women in dependent roles (Brodie, 2003, 55). As I illustrate below, the social question in the Polish case is animated by the reconfiguration of what constitutes European neoliberalism in the current epoch as the Polish state takes a leading role in institutionalising what Brodie terms the "new governing order" (Brodie, 2003, 58).

There are a number of paradoxes that emerge from Brodie's reading of the new governing order. First the paradox of scale where global problems are identified as a result of weak states; and then two that are the primary focus of this paper; second, the paradox of necessity where neoliberalism has undermined the processes that enable capitalist social relations to be reproduced and narrowed the options available to respond; and third the paradox of sustainability, where there is the simultaneous erosion and intensification of gender relations, virtually erased from policy making and delegitimised as the basis for claims, leading to the view that women's reproductive labour is, at best, an 'externality'; on the other hand, the gaps in social provisioning resulting from neoliberal rationalisation have increased demands on transnational flows of domestic and service workers who are largely women (Bakker, 2007, 542).

The latest iteration of neoliberalism is producing a renewed crisis of social reproduction.

These paradoxes relay the complex dialectics of neoliberalism and in the rest of this section the paper turns to one mechanism developed to respond to this paradox of necessity: policy interventions aimed at 'resolving' crisis that enable neoliberalism to 'fail forwards'.

Neoliberalisation in Eastern Central Europe is premised upon a set of development practices that alloy progress from the backwardness of the state socialist period and a better future achieved through reform. As Peck asserts, neoliberal reforms are always failing, but failing forwards and,

Can only exist in messy hybrids. Its utopian vision of a free society and a free economy is ultimately unrealizable. Yet the pristine clarity of its ideological apparition, the free market, coupled with the inevitable failure to arrive at this elusive destination, confer a significant degree of forward momentum on the neoliberal project. (Peck 2010: 7).

As with Brodie's paradox of necessity there is an inherent tendency in neoliberal strategies to fail forward because of the "manifest inadequacies that ... repeatedly [animate] further rounds of neoliberal invention" (Peck, 2010: 6) to more fully realise systemic transformative potential.

The paradox Brodie alerts us to is that there are always neoliberal solutions to neoliberal failures. Social reproduction is the latest neoliberal experiment in failing forwards. As Nunn indicates in a system where competition-competitiveness is a wired-in characteristic, many (and ultimately households and individuals) must inevitably fail ... the generalised characteristic of competitiveness mandates that the route out of failure is to further embed and internalise competitiveness (Nunn, 2019, xx).

Neoliberalism is "always ambivalent, always hybrid, always maintaining state power, always 
detouring around it, creating the constitution for its own failure." (Shields, 2019). There is constant modulation, articulation and innovation between actors at a variety of scales from the global to the local is constantly conflicted with the messy reality of neoliberalisation 'on the ground' and either delivering or failing, but always enabling further implementation. The current crisis in the region has concentrated the benefits, and diffused the losses before once again failing forwards. This section of the paper now turns to show how the paradox of necessity in fail forwards neoliberalism is manifest in the turn to recombinant populism in Eastern Central Europe.

One response to the current crisis, and what I would argue is the latest failing forwards of neoliberalism, has been a wave of anti-systemic political parties across Europe. Populism remains one of the most contested concepts in the social sciences; but broadly comprises antiestablishment attitudes; a preference for popular sovereignty of the 'people'; and a belief in the homogeneous virtuousness of the people, the 'us' and 'them' (Mudde, 2013). Most orthodox political science approaches to populism have attempted to configure classification of this inchoate concept. The main taxonomy is threefold. First, populism as a thin-centered ideology, that considers society to be ultimately separated into two "homogenous and antagonistic groups, 'the pure people' and 'the corrupt elite', and which argues that politics should be an expression of the volonté générale (general will) of the people" (Mudde 2004). Second a political strategy through which a charismatic leader exercises power based on direct support from the people from the population versus the elite (Jansen 2011). And third an appeal to 'the people' against both the established structure of power and the dominant ideas and values of society.

All involve some form of revolt against established power relations and in an epoch of neoliberalism that anti-elite discourse has found rich resonance in the sovereign 'people' being defrauded by corrupt elites. Though as Muller explains populism is "a particular moralistic imagination of politics, a way of perceiving the political world that sets a morally pure and fully unified - but, ultimately fictional - people against elites who are deemed corrupt or in some other way morally inferior" (Müller 2016: 26). As Brodie recalls, the populist revival shows that "powerful interests" have cultivated antipathy to the 'other' and to divert public attention away from the economic crisis ... breeding contempt for experts and science, [asserting] stark dichotomies in public discourses between taxpayers and freeloaders, public and private, and criminals and victims ... [amplifying] external threats at the expense of complex domestic problems (Brodie, 2012, 138).

In the Hayekian sense then, economic freedom precedes political, providing an easy ingress for the populists to reconcile with the neoliberals This is mutually reinforced "when marketfundamental reasoning is combined with right-wing populist political argumentation, the binary code of 'we' and 'they' is mutually reinforcing the binary code of 'the market' and 'the nonmarket"' (Ötsch and Pühringer, 2017, 502). Little wonder the reconciliation between populism and neoliberalism has been so straightforward to operationalise when even Hayek expressed that neoliberalism cannot be reduced to uniform right or left but a relentless experimentation (Hayek 2002: 5). In this way it becomes easier to glimpse how recombinant forms of populism, neoliberalism and a renewed assault on forms of social reproduction ensues. The next section of the paper probes how this happens in Poland.

\section{Poland and the paradox of recombinant populism}

The paper sets out to uncover how and why post-communist transition continues to build on a certain progressive content despite the populist and conservative elements dominating the current conjuncture. This has been situated in a discussion of the implications of the ongoing 
crisis across Europe, and then an attempt to bring Janine Brodie's neoliberal 'paradox of necessity' into dialogue with the fail forwards notion of neoliberalism to show how recombinant forms of populism are entirely reconcilable with neoliberal economic policies focused on social reproduction. In this section the paper draws its focus specifically on to Poland and thinks through the specificities of Poland's recombinant populism by unpacking two concerns, first detailing why Poland has found the populist appeal so seductive, and second highlighting the paradox that this transpired during a period of economic boom.

One of the main paradoxes of post-communist Poland is that a society 'rescued' from authoritarian rule by a social movement committed to worker self-government; self-management and the "self-liberation of civil society" was accompanied by the most extreme form neoliberal shock therapy (Bernard 1993: 10-3) in the transition from communism, with mixed results that ultimately generated a reactionary populist response. Solidarity claimed that the only level of inequality that could be tolerated between members of Polish society were those that would improve the conditions of the most disadvantaged (Solidarity 1981: 349). Since 1989 Poland has experienced impressive levels of economic growth. A then young, educated population with a series of business friendly governments induced high levels of foreign investment. Polish growth rates have outstripped the EU average by some distance (on average 4.1\% GDP growth from 1992 to 2016) and Poland remains the only EU state to avoid recession during the financial crisis (Piatkowski 2018). In contrast to the unalloyed positive news, it is worth remembering that conservative estimates contend 850,000 younger Poles are working in the UK, with over a million elsewhere in the EU raising doubts about the accuracy of unemployment data (Botterill \& Burrell 2018; Kaczmarczyk et al 2009). A question mark also hangs over the value of remittances sent to Poland from the rest of the EU, which are directed to those parts of the country that have benefitted most from the 500Plus programme. Poland also ranks badly in perceptions of corruption and the absence of government intervention had facilitated a sense of business as usual ignoring the population (Jasiewicz 2008; Hunter \& Domanska 2016).

The populist response in Poland to all of this has been to construct a variety of conspiracy theories around the usual social pathologies, ranging from a global liberal-left Jewish pact aimed at taking over the world, to fears that the EU and monetary union represent another attempt by Germany to reinstate Poland's peripheral position in the European political economy. This stems not only from a fear of national identity and culture, but also from the divisive sense that particular domestic social forces, the former Party nomenklatura, have benefitted from the transition and translated their previous power as state managers into power as the new postcommunist bourgeoisie. This is supplemented with a swirling concoction of xenophobic fears that historical enemies are trying to force Poland to accept a secondary role in the EU and the perception that the transition has exchanged Moscow's hegemony for that of Brussels. There is plentiful opportunity for Brodie's paradox of necessity to play out in Poland. A booming economy dominated by foreign investment but where paradoxically European problems are identified as a result of a weak Polish state; where neoliberalism has undermined the processes that enabled that weak state to reproduce neoliberalism; and where there is the simultaneous erosion and intensification of gender relations. In the rest of this section the paper offers some suggestive evidence how this emerged in Poland.

Poland has become dominated by foreign banks and retailers (Hunter 2018: 65): in recent years over $60 \%$ of Polish banks were foreign owned. By 2016 over half of manufacturing factories in Poland were foreign owned. Approximately 20 billion euros is transferred out of Poland due to foreign ownership. Over the transition period a number of traditional significant sectors have been severely weakened including mining, ship building, and steel; they have retrenched when foreign investors could not be found and the state refused to intervene. 
The first significant Polish response to this emerged in the early 2000s with the election of the first PiS coalition with Self-Defence (Samoobrona) and the League of Polish Families (Liga Polskich Rodzin, LPR) (see Shields 2013). The latter two, both particularly associated with a post-Solidarity populist critique of Poland's neoliberal transition. They contest the very legitimacy of the postcommunist system as a threat to Polish traditions and identity (Stanley, 2018) arguing that 'foreign' imports such as the state, (though not the nation) secularism, and liberal democracy should be replaced with more 'authentic' counterparts. As Stanley's close analysis uncovers, this coalition offered a sustained critique of neoliberal transition and an alternative populist narrative. PiS have further developed this narrative about real Poles, similar to the way Fidesz, talked about Hungarians (Stanley, 2018, 258-259).

The difficulty of responding to this is encapsulated in the current finance minister's policy, the Morawiecki Plan. The plan is configured around five pillars: 1) reindustrialising sectors where Poland has competitive advantage; 2) developing Polish innovations; 3) capital expenditure through a Polish Development Fund; 4) support for Polish exports; and 5) a social regional development programme including a 'demographic' programme (from Becker \& Weissenbache 2016; Gorynia, 2016; Mroczkowski \& Miller 2017). The paper returns to these issues in the next section. Becker and Weissenbache note, specific groups of the petit bourgeoisie and more generally the middle strata are seen as another core constituency. To differing degrees, right wing nationalist parties try to integrate certain sectors of the popular classes as well, particularly in smaller towns and in the countryside. Their social policies have a strongly exclusionary character and aim at re-affirming gender roles of the past (Becker \& Weissenbache 2016: 5 emphasis added).

While PiS may personify the values of self-reliance and self-governance, it is also unlikely that they violate globalising neoliberal ideals (Brodie 1996).

Poland has escaped relatively unscathed from the ongoing crisis of the Eurozone. PiS offered a very different version of the future in contrast to PO. This radical alternative ensured PiS won the 2015 parliamentary elections ${ }^{1}$ with an intoxicating mix of "authoritarian populism" that has "led to intensifying xenophobia, aggressive nationalism, and unprecedented polarization that have given rise to social protest movements not seen in Poland since 1989" (Fomina \& Kucharczyk 2016). As elsewhere in Europe, the broader context for the emergence of populism has been the crisis of neoliberalisation. This is a familiar set of populist tropes: the losers of globalisation, the cultural challenge of immigration, and the erasure of national political identity by European level politics all promoted by a disassociated cosmopolitan, urban technocratic Europhile elite, or what Dawson and Hanley describe as an "elite project driven by small groups at the apex of politics, business, academia, and officialdom" (Dawson \& Hanley 2016: 21).

\section{Recombinant populism and the new Polish capitalism}

I use the term recombination here as a way of engaging with and clarifying the ongoing definitional difficulties of populism. I am less concerned with its form, more its social content. Populism has become "an abbreviated and generic term covering a variegated phenomenon" that is "not of capitalism but certainly in it" (Colas, 2004: 15). Recombination helps to problematise the apparent separation of populism from capitalism evident in much of the existing political science literature and to think through their intertwining. Recombination theorises the political, social and economic logics that instantiate populism as a way of reconfiguring multiple forms of hybrid political mobilisations. Recombinant populism highlights the admixture of contradiction, institutionalisation, contestation and mobilisation around claims 
for reform in Poland since the imposition of neoliberalism.

Since 2015 then PiS have done much to illustrate that the populists can govern as effectively as their neoliberal technocratic counterparts. These ideas and policies emerge through a hegemonic project "that stems from the economic sphere, but which is broad enough to incorporate diverse and even partly antagonistic ideas" (Bohle, 2006: 62). In a rejection of the hegemonic transition mainstream, Poland has begun to reorient the development trajectory for post-communist Eastern Central Europe. Under some measurements Poland is catching up with Portugal's GDP per capita and exceeded Greece. Oxfam's 2018 index of social spending listed Poland as spending most to reduce inequality. Polish capitalism is configured around a discourse of solidarism. PiS leader Jaroslaw Kaczynski outlined what this means,

We have a great goal. This great goal is to make Poland, our homeland, a country equal to our neighbours to the West in terms of economic development, quality of life, while maintaining its identity, its values, its faith, that is, its freedom ... we will not build a Dubai, but would it not be possible ... to build a Polish Bavaria here? (PAP October 7 2018).

This will be achieved through a Polonisation of the economy, or what is sometimes known as domification. Domification has an interesting etymology, mixing meanings related to astrology and the home (in Polish - dom) which links to the cosmological and nationalist claims of the more extreme end of PiS. Domestic investors and the Polish state will encourage national ownership of the sectors sold off at the start of the transition as part of the spontaneous privatisation of the early 1990s that legitimised the theft of public assets under the euphemism of nomenklatura privatisation that emanates across the region not just Poland (Gagyi \& Ivancheva, 2019, 61).

As the current Polish Prime Minister Mateusz Morawiecki explained at an address to the Congress590 conference,

It turns out that the rules of capitalism are not sacred, inviolable and uniform.

Capitalism is different in different countries ... Capitalism must be a social capitalism, pro-social but also creating good living conditions for entrepreneurs and companies.

Solidarism should be that economic system (https://www.fakt.pl/pieniadze/finanse/kongres-590-mateusz-morawicki-)

The new Polish capitalism channels the social conservatism, Catholicism and commitment to higher welfare state spending in contrast to its preceding neoliberal transition version. On appointment, Marowiecki told the Polish parliament that capitalism in English-speaking countries,

is clearly not coping too well with inequalities. French and Italian capitalism is not coping too well with competitiveness ... in the new Polish economic and social model we are demonstrating to Europe how social solidarity can be coupled with dynamic economic development (Morawiecki 2017 speech).

While the PiS government may well be far to the right in terms of nationalist religious conservatism there is the contradiction of seemingly progressive social policy reforms. A recent major report by the PiS connected think tank the Institute for Market, Consumption and Business Cycles Research, called Capitalism: The Polish Way emphasised inclusive social and economic policy. While this might not appear too unusual, the report clarifies that the previous model was "externally imposed" (IMCBCR 2018: 35).

The social policy centre piece of the new Polish capitalism has been the 500Plus programme explicitly configured around the importance of family policy to social reproduction in the 
current crisis of neoliberalism. Poland's low birth rate, one of the lowest in the EU, is impacting on economic development and challenging existing cultural norms with recent increased migration (Sowa 2015; White et al., 2018). There is a sense of déjà vu surrounding high levels of immigration from once welcomed as one way of boosting the birth rate. Of course in the 1920s those migrants came from Poland. PiS's 500Plus programme is designed to encourage childbirth and reduce child poverty. The universal child benefit ensures that families get 500 złoty (approximately €115) for every child from the second onwards. In families with a houseful income below 800 złoty per capita per month it commences with the first child, and 1200 złoty in the case of disability (GUS 2015). To lend a little context, in 2016 when the policy was introduced 500 złoty was $40 \%$ of the minimum wage.

The problem for the more committed neoliberals is that 500Plus has worked. According to the World Bank 500Plus has significantly impacted on child poverty since 2016 (Goraus \& Inchauste 2016). Polish GUS data reveals that children living in poverty fell significantly from $9 \%$ to $6 \%$ and even further in the latest data available for 2017 (GUS 2018b: 170)

A significant decrease in the poverty range was observed especially among such groups as: large families (with 3 and 4 or more dependent children), households with disabled people, inhabitants of rural areas and towns with less than 20,000 inhabitants, and households with head of households (GUS 2018a: 1)

Further investigation shows that the increased welfare intervention has been directed towards educational activities, and domestic tourism (GUS 2018b).

The impact on the other side of the social reproductive intervention is less clear cut. The fertility rate has increased slightly with the average number of children born increasing from 1.289 in 2015, 1.357 in 2016 and 1.43 in 2017 across the period of the 500Plus policy (GUS2018b: 106). This timescale has also coincided with a booming economy, low unemployment and rising wages in Poland. What there is clear evidence of is one of the contradictions of social reproduction interventions during neoliberal crisis: women are leaving the workforce. An Institute for Structural Research (IBS) in Warsaw report reinforces this point, illustrating that, the recent introduction of [500Plus] had a significantly negative impact on labour force participation and employment of eligible mothers ... The effects are sizeable implying that labour force participation and employment would have been between $21 / 2$ and 3 per cent higher by mid-2017 in the absence of the reform. Testing for heterogeneity across different groups reveals that the effects are strongest for the lowest-educated mothers ... At a later stage it will also be interesting to assess whether fertility is influenced positively by the benefit, as intended by the government. It will be challenging to identify the reform effect, though, as the booming economy, the general rise in incomes in Poland, the much improved labour market situation and better access to childcare services have all helped to make it easier for families to have more children (Magda et al 2018: 17).

The IBS research estimates that approximately 100,000 women left the labour market in the first half of 2017 due to 500Plus. Or as Morawiecki puts it, "The task of the region, but first of all of Poland, is to try to find new solutions for the EU, so that various development models have the chance to coexist and create conditions for sustainable development" (Morawiecki 2017 speech). That development model continues to invoke the rationality of economic growth alongside policy and discursive justifications for shifting certain parts of the population into, out of and alongside the formal economy within social programmes aimed at specific groups, in this case, women.

500Plus simultaneously propels the crisis of care and the crisis of neoliberalism into the 
household. For Poland this means the configuration of

a set of norms about gender and its relationship to the household division of labor to valorize a certain conceptualization of the subject. It attempts to restructure behaviors by reforming households to be more like a ideal of heterosexual coupledom (Bergeron 2011: 159).

One of the recombinations in populist discourse invokes a particular view of the nation. Recall that this is a crucial social sedimentation in the Polish case. A golden period from the past is projected into the present when Polish national identity was bound together by the traditional family. On the one hand PiS are guardians of the nation's future through the reproduction of Polish children through future generations (who will be white, Christian and heterosexual). On the other, PiS are also 'guardians' of a project that reproduces certain capitalist social relations. Alongside other practices of nativism, gendered representations of the nation are a mechanism for the capitalist state to reconcile continuity and change (see Erel 2017).

\section{Conclusion}

The paper asked how and why regressive recombinant populist governments have promoted outwardly progressive forms of social reproduction in the context of the supposed crisis of neoliberalism. Why is that a government supposedly of the far right in Poland have offered the most progressive welfare intervention since the collapse of communism in the region? The paper responded to this by framing the current conjuncture in Poland as a paradox of the new constitutionalism, unravelling what happens when a form of ostensible resistance becomes juridically sealed into a society. At its most socially corrosive an attempt to resist neoliberalism leads to its reinforcement. The paper developed this argument in relation to Brodie's three paradoxes: of scale, of necessity, and of sustainability, in so far as the resistance that results in more progressive forms of social reproduction in order to deal with the crisis mode of society in effect helps to ensure its continuation through another iteration of forwards failure.

One consequence of these paradoxes in the failing forwards of neoliberalism in Poland, and ever more perceptibly elsewhere in Europe, is that the traditional dividing lines between left and right are ever more blurred in different social, political and cultural configurations in a potent mix of nostalgia, a sense of decline, and political resentment. This throws up some interesting problems with many of the more straightforwardly accepted notions of neoliberalism, especially the notion of neoliberalism as endpoint. Hence the paper began to show the utility of bringing Brodie's paradoxes into dialogue with the fail forwards neoliberalism literatures. Gendered identities construct and are constructed by neoliberal influences and subjectivities of the current order. As with the recombinant populism this is all achieved while negotiating the differing structures of the previous regime and the new, recombining prima facie disparate policies and intentions.

Drawing on the Polish case of the Morawiecki Plan's Plus500 policy further compounds how ideas of gender, of the social construction of norms of what constitutes masculinity and femininity are at the foreground of neoliberal post-communist transition and necessitates a more holistic critique of relations of domination, inequality and injustice amid the mobilisation of neoliberal cooption. The wider implication of this is the challenge that the new Polish model represents to rethinking the existing European political economy. Rather than challenging neoliberalism welfare intervention as enabled yet another failure forwards, configuring a further round of commodification of social reproduction in the 500Plus policy. What this also illustrates is the necessity for further critical investigation to explore the current formulation of social reproduction in a period of renewed populism around Europe. What at first blush might appear 
to be potentially progressive in intent instead reinforces the reprivatisation of social reproduction under neoliberalism. 


\section{Bibliography}

Babidge, S. \& Belfrage, M. (2017) Failing forward: A case study in neoliberalism and abandonment in Calama. Cultural Dynamics, 29, 235-254.

Bakker, I. (2007) Social reproduction and the constitution of a gendered political economy. New Political Economy, 12, 541-556.

Becker, J. \& Weissenbacher, R. (2016) Heterodoxy from the Right: Economic Policy Concepts of the Nationalist Right in Europe. EuroMemo Group Conference Paper.

Bohle, D. \& Greskovits, B. (2012) Capitalist Diversity on Europe’s Periphery. Cornell University Press, Ithaca.

Botterill, K. \& Burrell, K. (forthcoming) (In)visibility, privilege and the performance of whiteness in Brexit Britain: Polish migrants in Britain's shifting migration regime. Environment \& Planning C: Politics and Space.

Brodie, J. (2003) Globalization, In/Security and the Paradoxes of the Social. (Eds, Bakker, I. \& Gill, S.) Palgrave Macmillan, Basingstoke, pp. 47-65.

Brodie, J. (2012) Social literacy and social justice in times of crisis. Trudeau Foundation Papers, $4,117$.

Colas, A. (2004) The Re-Invention of Populism: Islamist Responses to Capitalist Development in the Contemporary Maghreb. Historical Materialism, 12, 231-260.

Connolly, R. (2012) The Determinants of the Economic Crisis in Post-Socialist Europe. EuropeAsia Studies, 64, 35-67.

Development Finance International \& Oxfam (2018) The commitment to reducing inequality index 2018.

Dowling, E. (2016) Valorised but not valued? Affective remuneration, social reproduction and feminist politics beyond the recovery. British Politics, 11(4) 452-68.

Erel, U. (2017) Saving and reproducing the nation: Struggles around right-wing politics of social reproduction, gender and race in austerity Europe. Women's Studies International Forum, doi.org/10.1016/j.wsif.2017.11.003.

Gagyi, A. \& Ivancheva, M. (2019) The reinvention of 'civil society': transnational conceptions of development in East-Central Europe. Funding, Power and Community Development, 55.

Gibson-Graham, J.K. (2006) A postcapitalist politics. University of Minnesota Press, Minneapolis.

Gill, S. (1995) Globalisation, market civilisation, and disciplinary neoliberalism. Millennium, 24(3) 399-423.

Goraus, K. \& Inchauste, G. (2016). The Distributional Impact of Taxes and Transfers in Poland. Policy Research Working Paper; No. 7787. World Bank, Washington, DC.

Gorynia, M. (2016) The Polish economy: achievements, failures and development opportunities Economics and Business Review, 2(4) 92-114

Gramsci, A. (1971) Selections from the Prison Notebooks. Lawrence and Wishart, London.

GUS 2018a Concise Statistical Yearbook of Poland

GUS 2018b Range of economic poverty in Poland in 2017

Hardy, J. (1998) Cathedrals in the Desert? Transnationals, Corporate Strategy and Locality in Wroclaw. Regional Studies, 32(4) 639-652.

Hardy, J. (2014) Transformation and crisis in Central and Eastern Europe: A combined and uneven development perspective. Capital \& Class, 38, 143-155.

Hayek, F.A. (2002) Competition as a Discovery Procedure, 5 Journal of Austrian Economics $9(10)$.

Hörschelmann, K. (2002) History after the end: post-socialist difference in a (post) modern world. Transactions of the Institute of British Geographers, 27, 52-66.

Hunter, RJ (2018) Poland's Sustained "March to a Market Economy": The Choice Between Competing Visions and Plans Research in World Economy Vol. 9, No. 1;

Hunter, RJ \& Domanska, M. (2016). Poland: A Country Study - Europe's Poster Child to 
Europe's Problem Child. Issues in Economics and Business, 2(1): 15-27.

Jasiewicz, K. (2008) The New Populism in Poland: The Usual Suspects?, Problems of PostCommunism, 55:3, 7-25, DOI: 10.2753/PPC1075-8216550302

Kaczmarczyk P., Mioduszewska M., and Żylicz A. (2009) Impact of the Post-Accession Migration on the Polish Labor Market. In: Kahanec M., Zimmermann K. (eds) EU Labor Markets After Post-Enlargement Migration. Springer, Berlin, Heidelberg.

Magda, I., Kiełczewska, A. \& Brandt, N. (2018) The Family 500+ child allowance and female labour supply in Poland. Institute for Structural Research. Warsaw.

Mroczkowski, T. \& Miller, M. (2017) Envisioning Smart Development in Poland from a Triple Helix Systems Perspective: a Critical Assessment of the Morawiecki Plan. Journal of the Knowledge Economy 8(2): 513-35. https://doi.org/10.1007/s13132-017-0486-9

Mudde, C. (2013) Three decades of populist radical right parties in Western Europe: So what. European Journal of Political Research, 52, 1-19.

Müller, J.-W. (2016) What is Populism? Philadelphia: Pennsylvania University Press.

Myant, M., Drahokoupil, J. \& Lesay, I. (2013) The Political Economy of Crisis Management in East-Central European Countries. Europe-Asia Studies, 65 (2) 383-410.

Nunn, A. (2019) Review of International Political Economy.

Orenstein, M. (2014) From Tragedy to Triumph. Foreign Affairs, 93(1), 23-27.

Ötsch, W.O. \& Pühringer, S. (2017) Right-wing populism and market-fundamentalism. Journal of Language and Politics, 16, 497-509.

PAP (Polska Agencja Prasowa) Ruling party chief wants to make Poland as rich as West, 7 October 2018.

Peck, J. (2010) Constructions of Neoliberal Reason. Oxford University Press, Oxford.

Peck, J. Theodore, N. and Brenner, N. (2012) 'Neoliberalism resurgent? Market rule after the great recession'. The South Atlantic Quarterly 111(2): 265-288.

Piatkowski M. (2018) Europe's Growth Champion: Insights from the Economic Rise of Poland, Oxford University Press, Oxford.

Rai, S.M., Hoskyns, C. \& Thomas, D. (2014) Depletion. International Feminist Journal of Politics, 16(1) 86-105.

Shields, S. (2012) The International Political Economy of transition: Neoliberal hegemony and Eastern Central Europe's transformation. Routledge, London.

Shields, S. (2019) Defining, censuring, and resolving: the EBRD, collective organic intellectuals and the global financial crisis in Eastern Central Europe. Globalizations, 1-19.

Soederberg, S. (2014) Debtfare States and the Poverty Industry: Money, Discipline and the Surplus Population. London: Routledge.

Sowa A. (2016) "Family 500+": A new family income-supporting benefit in Poland, European Social Policy Network ESPN Flash Report 2016/45

Stanley, B. (2015) "The Post-Populist Non-Crisis in Poland," in European Populism in the Shadow of the Great Recession, ed. Hanspeter Kriesi and Takis Pappas, (Colchester: ECPR Press), 258-59.

Stanley, B. (2018) A New Populist Divide? Correspondences of Supply and Demand in the 2015 Polish Parliamentary Elections. East European Politics and Societies: and Cultures. https://doi.org/10.1177/0888325418783056.

Van Hoven, B. (2004) Women's lives in transition: 'everything gets better but nothing is good', in: East Central Europe and the former Soviet Union. The Post-Socialist States, edited by: Bradshaw, M. and Stenning, A. Prentice Hall, London, pp. 161-186.

White, A. et al. (2018) The Impact of Migration on Poland. UCL Press, London.

Wöhl, S. (2014) The state and gender relations in international political economy: A statetheoretical approach to varieties of capitalism in crisis, Capital \& Class, https://doi.org/10.1177/0309816813513089 38(1) 87-99. 


\section{Notes}

${ }^{1}$ As with other examples of the populist turn the neoliberal mainstream PO, suffered from a disenchanted electorate who turned to PiS, Nowczesna an even more neoliberal alternative, and the Kukiz ' 15 movement led by rockstar Pawel Kukiz that denied any specific ideological position. 